\title{
ANALISIS MULTIDIMENSIONAL PEMBELAJARAN AKIDAH AKHLAK BERBASIS MULTIPLE INTELLIGENCES DAN DAMPAKNYA BAGI SIKAP KEAGAMAAN SISWA MADRASAH ALIYAH BENGKULU SELATAN
}

\author{
Arief Rahman \\ Program Pascasarjana \\ Universitas Islam Negeri Raden Fatah Palembang \\ E-mail: ariefrahman7722@yahoo.com
}

\begin{abstract}
Abstrak
Keberhasilan pembelajaran tidak terlepas dari berbagai komponen yang menjadi pendukung dalam pembelajaran, dimana komponen pendukung tersebut sudah semestinya dibuat dengan baik. Demikian juga dalam proses pembelajaran yang seharusnya menarik, agar siswa dapat memahami pembelajaran. Sikap siswa yang kurang baik salah satu faktornya dapat disebabkan karena kurangnya pemahaman siswa akan materi pembelajaran akidah akhlak. Bila siswa memahami dengan baik, tentunya akan berdampak pada sikap siswa itu sendiri. Jenis penelitian ini adalah mixed methods (penelitian campuran) kualitatif-kuantitatif, dengan sequential exploratory designs, yaitu pengumpulan data kualitatif dilakukan pertama kali dan dianalisis, kemudian data kuantitatif dikumpulkan dan dianalisis. Metode ini dengan bobot metode kualitatif lebih tinggi daripada kuantitatif (QUAL + quan). Sedangkan teknik pengumpulan datanya adalah observasi, wawancara, dokumentasi, dan angket, dengan menggunakan teknik analisis data kualitatif yang bersifat induktif dan teknik analisis isi untuk dokumen. Sedangkan analisis data kuantitatif digunakan untuk mengetahui dampak pembelajaran aversion therapy dan modelling bagi sikap keagamaan siswa Madrasah Aliyah Bengkulu Selatan.
\end{abstract}

Kata Kunci : Multidimensi, Pembelajaran, Akidah Akhlak, Multiple Intelligences, Sikap Keagamaan, Aversion Therapy, Modelling.

\footnotetext{
Abstract

The success of learning can not be separated from the various components that become supporters in learning, where the supporting components are already properly made. Similarly, in the learning process that should be interesting, so that students can understand learning. Bad student attitudes one of the factors can be caused by the lack of
}

understanding of students about the material of moral aqidah. When students understand well, it will certainly have an impact on the attitude of the students themselves. This type of research is mixed methods (qualitative-quantitative research), with sequential exploratory designs, which is collecting qualitative data first and analyzed, then quantitative data is collected and analyzed. This method with the qualitative method weight is higher than quantitative (QUAL + quan). While the data collection techniques are observation, interview, documentation, and questionnaire, using qualitative data analysis techniques that are inductive and content analysis techniques for documents. While quantitative data analysis is used to know the impact of aversion therapy learning and modeling for the religious attitude of Madrasah Aliyah students of South Bengkulu.

Keywords: Multidimensional, Learning, Akidah Akhlak, Multiple Intelligences, Religious Attitude, Aversion Therapy, Modelling

Manusia adalah makhluk sosial yang membutuhkan bantuan dan pertolongan orang lain, dan juga berinteraksi serta berhubungan antar satu dengan yang lainnya. Manusia juga diciptakan dengan memiliki tingkat kemampuan kecerdasan yang berbeda-beda pula. Hal inilah yang sangat ditekankan dalam dunia pendidikan. Tingkat kecerdasan tersebut dapat membawa manusia kepada kehidupan yang lebih baik.

Sejalan dengan upaya dalam rangka menumbuhkembangkan potensi kecerdasan peserta didik, telah banyak bermunculan lembaga pendidikan baik formal maupun non formal, diantaranya adalah Madrasah Aliyah yang ada Kabupaten Bengkulu Selatan. Sebagai warga Madrasah Aliyah tentunya para siswa memiliki sikap keagamaan yang baik. Akhlakul karimah dapat tercermin dalam kehidupan sehari-hari. Sopan santun sangat diutamakan untuk 
menjaga keakraban antar warga Madrasah Aliyah. Saling menghormati selalu diajarkan kepada siswa untuk menghargai antar sesama. Demikian juga halnya dengan disiplin yang tinggi yang merupakan bagian dari ajaran Islam yang selalu ditekankan kepada pada para siswa dalam menuntut ilmu pengetahuan umum dan juga ilmu agama. Patuh pada guru dan orang tua merupakan perwujudan dari akhlak yang baik pula. Saling memberi dan mengucapkan salam adalah hal biasa yang selalu dilakukan. Perilaku tersebut sejalan dengan apa yang diungkapkan oleh Zakiah Darajat, sebagaimana yang dikutip oleh Abuddin Nata (2010) mengatakan bahwa perilaku seseorang yang yang tampak lahiriah terjadi karena dipengaruhi oleh keyakinan yang dianutnya. Seseorang ketika berjumpa saling mengucapkan salam, hormat kepada kedua orang tua, kepada guru, menutup aurat, rela berkorban untuk kebenaran, dan sebagainya merupakan gejala-gejala keagamaan yang dapat dijelaskan melalui ilmu jiwa agama.

Selain dari itu, siswa Madrasah Aliyah juga sangat identik dengan suasana keagamaan yang kuat. Sholat sebagai tiang agama selalu ditegakkan dengan cara menunaikannya lima kali sehari semalam tanpa ditinggalkan. Puasa sunnah sudah merupakan kebiasaan bagi para siswanya. Membaca dan menghafalkan al-Qura'an bukan dianggap sesuatu hal yang asing bagi siswa madrasah. Demikian juga dengan pelajaran ilmu-ilmu agama lainnya, seperti ilmu-ilmu Kalam, al-Qur'an Hadits, Fiqih, kesemuanya merupakan bagian dari ilmu yang dituntut oleh siswa Madrasah Aliyah. Begitu juga dengan kebersihan dan kerapian merupakan tuntunan yang selalu dianjurkan pada para siswa. Suasana belajar yang kondusif dan penuh semangat mewarnai setiap kegiatan pembelajaran, dan juga didukung dengan sarana prasarana yang cukup memadai, yang kesemuanya dapat meningkatkan pencapaian kulitas belajar yang baik. Siswa Madrasah Aliyah juga dibekali dengan ilmu-ilmu pengetahuan umum. Hal ini dimaksudkan agar siswa Madrasah Aliyah dapat memiliki kompetensi yang tinggi yang setara dengan sekolah-sekolah umum lainnya.

Fenomena tersebut di atas menggambarkan bagaimana idealnya keadaan Madrasah Aliyah yang menjadi tempat idaman bagi peserta didik dalam menuntut ilmu pengetahuan umum dan juga ilmu pengetahuan agama Islam. Namun ternyata tidaklah demikian keadaan Madrasah Aliyah kota Manna yang ada di kabupaten Bengkulu Selatan.

Berdasarkan observasi awal yang telah dilakukan oleh peneliti pada Madrasah Aliyah Bengkulu Selatan, data yang berhasil dihimpun oleh peneliti antara lain adalah sebagai berikut:

Pertama, observasi yang telah dilakukan di Madrasah Aliyah Negeri Manna Bengkulu Selatan menemukan beberapa pelanggaran terhadap sikap keberagamaan yang dilakukan oleh siswa, antara lain adalah siswa lebih senang menghabiskan waktu mereka dengan bermain pada waktu sholat zhuhur tiba. Beberapa siswa juga harus selalu diperintah dan diperingatkan, untuk melaksanakan sholat zhuhur berjamaah, karena belum ada kesadaran sendiri untuk menunaikannya. Hal ini diperparah lagi dengan beberapa siswa yang jarang masuk sekolah ataupun membolos, malas belajar serta melakukan pelanggaran tata tertib sekolah lainnya seperti berkelahi, berpacaran, merokok, mencuri dan lainlain yang semuanya dilakukan siswa pada jam sekolah.

Kedua, berdasarkan observasi yang telah dilakukan oleh peneliti pada Madrasah Aliyah Al Qur'aniyah Bengkulu Selatan menemukan bahwa sikap keberagamaan siswa pada Madrasah ini tidak jauh berbeda dengan keadaan siswa Madrasah Aliyah Negeri Manna. Padahal Madrasah Aliyah Al Quraniyah merupakan pondok pesantren dibawah naungan yayasan Affan.

Walaupun Madrasah Aliyah ini adalah bagian dari pondok pesantren, namun sikap keagamaan siswa belum muncul dalam perilaku siswa sehari-hari. Hal ini disebabkan karena kurang ditegakkannya disiplin dan kurangnya pengawasan dari pihak yayasan. Adapun dampak dari hal tersebut, siswa Madrasah Aliyah ini sulit untuk diatur dalam menjalankan perintah agama Islam. Para siswa lebih senang bertindak menurut kehendak mereka dengan tidak memperdulikan aturan yang telah ditetapkan, sehingga para siswa Madrasah ini dapat lebih santai dalam mengikuti proses belajar mengajar di Madrasah. Bahkan para siswanya banyak yang bolos dan tidak masuk kelas hingga beberapa hari.

Ketiga, berdasarkan observasi yang telah dilakukan oleh peneliti pada Madrasah Aliyah Makrifatul 'Ilmi Bengkulu Selatan menemukan bahwa, sikap keagamaan siswa pada madrasah ini menunjukkan kearah yang positif dibandingkan dengan siswa Madrasah Aliyah Negeri dan Madrasah Aliyah Al Quraniyah. Hal ini disebabkan antara lain karena madrasah ini adalah bagian dari pondok pesantren Makrifatul 'Ilmi, dan siswa pada madrasah ini adalah para santri pada pondok tersebut. Sehingga sikap keagamaan benar-benar dibimbing dan diterapkan dalam setiap sendi kehidupan. Namun demikian ada beberapa siswa yang masih berat dalam melaksanakan shalat karena belum terbiasa mengerjakannya.

Melihat dari gambaran keadaan siswa Madrasah Aliyah kota Manna kabupaten Bengkulu Selatan tersebut, peneliti berpikir kiranya perlu diujicobakan suatu teori pembelajaran baru, yang dapat membantu peserta didik dalam meningkatkan kualitas belajar siswa, sehingga dapat berdampak pada sikap keagamaan mereka. 


\section{Hasil Penelition}

Belajar

Banyak sekali definisi yang dikemukakan oleh para ahli tentang pengertian belajar. Menurut Slameto, belajar ialah suatu proses usaha yang dilakukan seseorang untuk memperoleh suatu perubahan tingkah laku yang baru secara keseluruhan, sebagai hasil pengalamannya sendiri dalam interaksi dengan lingkungannya. Hal ini sejalan dengan apa yang disimpulkan oleh Rohmalina Wahab bahwa, belajar adalah semua aktivitas mental atau psikis yang dilakukan oleh seseorang sehingga menimbulkan perubahan tingkah laku yang berbeda antara sesudah belajar dan sebelum belajar.

Dengan beberapa pengertian belajar di atas, maka yang dimaksud dengan belajar adalah seluruh aktifitas fisik dan mental yang dilakukan oleh seseorang, sehingga menimbulkan perubahan tingkah laku yang berbeda terhadap dirinya, dari tingkah laku sebelum belajar kepada tingkah laku setelah belajar.

Belajar pada hakikatnya adalah mencari, memperoleh, ataupun mendapatkan ilmu dengan harapan terjadi perubahan pada diri seseorang, dari yang sebelumnya tidak tahu menjadi tahu, dari yang sebelumnya tidak mengerti menjadi mengerti, dan seterusnya. Menurut Wahab, hakikat belajar adalah kegiatan yang dilakukan secara sadar oleh seseorang yang menghasilkan perubahan tingkah laku pada diri sendiri, baik dalam bentuk pengetahuan dan keterampilan baru maupun dalam bentuk sikap nilai yang positif.

Dengan demikian hakikat belajar pada prinsipnya terjadi perubahan tingkah laku yang lebih baik, antara sebelum belajar dan sesudah belajar. Namun demikian perubahan tersebut dapat saja terjadi oleh beberapa hal yang bukan merupakan hasil belajar. Oleh karena itu diperlukan pemahaman yang benar akan konsep belajar itu sendiri, agar selama pelaksanaan prose belajar mengajar betulbetul dapat bermakna dan mendatangkan hasil yang maksimal.

Dengan demikian dapat disimpulkan bahwa, perubahan-perubahan yang terjadi pada diri individu merupakan akibat dari proses belajar. Dengan belajar seseorang dapat mengetahui hal-hal yang baru yang belum diketahuinya. Sehingga seseorang akan terus belajar untuk menemukan hal-hal baru yang belum diketahuinya.

\footnotetext{
Model Modifikasi Tingkah Laku (behavior modification models)

Model pembelajaran ini bertitik tolak dari teori behavioristik. Model ini pada mulanya dikembangkan melalui eksperimen terhadap kondisi yang bersifat klasikal oleh Pavlov, yang kemudian dikembangkan oleh Thorndike dalam bentuk sistem reward didalam pembelajaran. Model tersebut bermaksud mengembangkan sistem-sistem yang efesien untuk memperturutkan tugas-tugas belajar
}

dan membentuk tingkah laku dengan cara memanipulasi penguatan (reinforcement). Para eksponen teori reinforcement tersebut seringkali menunjuk kepada teori modifikasi tingkah laku yang menitikberatkan pada perubahan tingkah laku eksternal siswa visible behavior lebih dari tingkah laku yang mendasarinya dan yang tak dapat diamati. Peneliti menginovasi dari desain model pembelajaran dengan pendekatan psikoanalisa melalui metode Aversion Therapy dan Home Work untuk mengatasi penyimpangan sosial peserta didik siswa SMK/SMA, yang dilakukan oleh Y.Yunie (2015). Inovasi desain ini menggunakan pendekatan behavioristik dan humanistik melalui metode aversion therapy dan modeling berbasis Multiple Intelligences yang sebelumnya tidak ada.

\section{Desain Behavior Modification Models}

Desain Behavior Modification Models

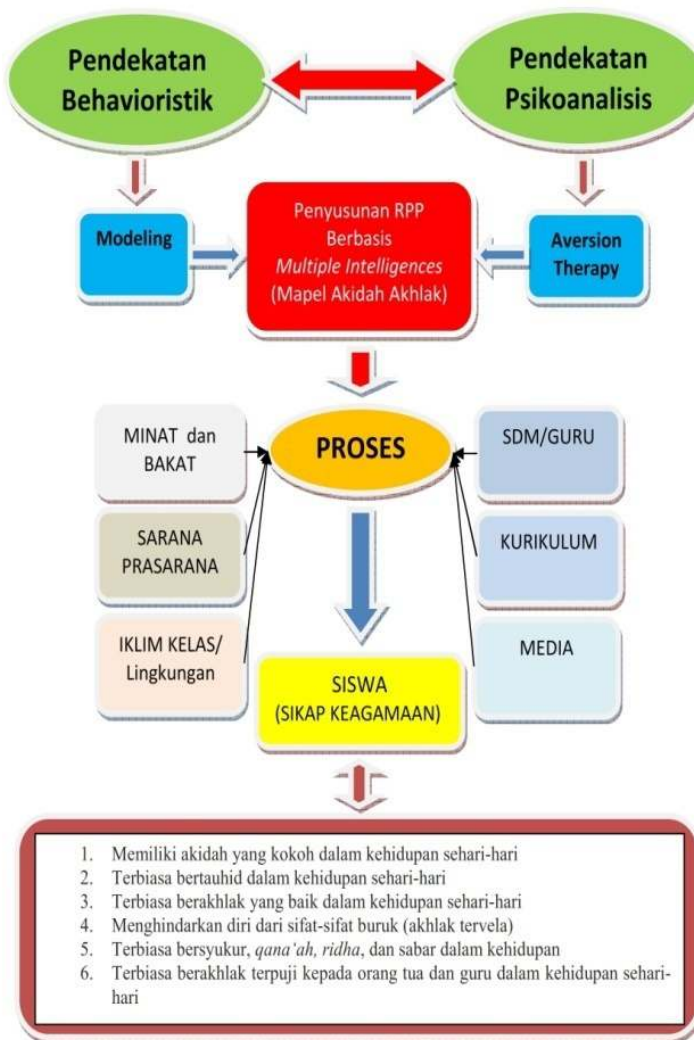

\section{Metode Aversion Therapy}

Metode aversion therapy adalah suatu suatu teknik yang bertujuan untuk menghukum siswa karena telah melakukan perbuatan yang menyimpang.Metode ini dapat diterapkan dalam pembelajaran untuk mengubah perilaku yang kurang baik pada diri peserta didik di sekolah dengan memperlihatkan suatu hukuman atau azab bagi seseorang yang berbuat perilaku yang menyimpang. Dalam proses belajar mengajar guru dapat 
menanyangkan sebuah film yang memperlihatkan kegetiran dari siksa kubur serta keadaan neraka sehingga hati peserta didik menjadi luluh dan mereka takut atau merasa jera untuk berbuat hal yang menyimpang, lalu ditanyangkan pula sebuah renungan perjalanan hidup yang pernah dilalui seorang anak dari mulai lahir, tumbuh besar dimulai dengan menjalani usia taman kanak-kanak, lalu usia sekolah dasar, usia sekolah menengah, ke bangku kuliah sampai dia berhasil menjadi seorang pegawai, disitu bagaimana sikapnya terhadap orang tua, terhadap seorang ibu yang dengan susah payah melahirkan dan membesarkannya. Hal ini akan menyadarkan psikis dari anak tersebut, akan merasa terketuk hatinya untuk sayang dan berbakti terhadap orang tuanya.

\section{Metode Modeling}

Pembelajaran sikap seseorang dapat dilakukan dengan melalui proses modeling, yaitu pembentukan sikap melaui proses asimlasi atau proses mencontoh. Salah satu karakteristik anak didik yang sedang berkembang adalah keinginannya untuk melakukan peniruan (imitasi). Hal yang ditiru itu adalah perilaku-perilaku yang diperagakan atau didemonstrasikan oleh orang yang menjadi idolanya. Prinsip peniruan inilah yang disebut dengan modeling. Menurut Wina Sanjaya, modeling adalah proses peniruan anak terhadap orang lain yang menjadi idolanya atau orang yang dihormatinya. Pemodelan biasanya dimulai dari perasaan kagum. Secara perlahan perasaan kagum akan memengaruhi emosinya, dan secara perlahan itu pula anak akan meniru perilaku yang dilakukan oleh idolanya itu. Jadi pembelajaran melewati modeling ini adalah awal mula anak melakukan perubahan sikap mereka dengan mencontoh atau mengidolahan seseorang yang mereka kagumi. Namun demikian diharapkan pada akhirnya anak dapat memahami sikap tertentu yang benar-benar dapat muncul dan didasari suatu keyakinan bahwa apa yang mereka lakukan adalah benar adanya.

\section{Akidah Akhlak}

Secara etimologi (bahasa) akidah berasal dari kata "aqada-ya'qidu-aqdan", berarti ikatan perjanjian, sangkutan dan kokoh. Disebut demikian, karena ia mengikat dan menjadi sangkutan atau gantungan segala sesuatu. Dalam pengertian teknis artinya adalah iman atau keyakinan. Menurut istilah (terminologi) akidah ialah dasar-dasar pokok kepercayaan atau keyakinan hati seorang muslim yang bersumber ajaran Islam yang wajib dipegang oleh setiap muslim sebagai sumber keyakinan yang mengikat. Syaikh Abu Bakar Al-Jaziri (2000) menyatakan bahwa akidah adalah kumpulan dari hukum-hukum kebenaran yang jelas yang dapat diterima oleh akal, pendengaran dan perasaan yang diyakini oleh hati manusia dan dipujinya, dipastikan

\section{Haril Penclition}

kebenarannya, ditetapkan keshalehannya dan tidak melihat ada yang menyalahinya dan bahwa itu benar serta berlaku selamanya. Seperti keyakinan manusia akan adanya Sang Pencipta, keyakinan akan ilmu kekuasaan-Nya, keyakinan manusia akan kewajiban ketaatan kepada-Nya dan menyempurnakan akhlakyang dimaksud aqidah dalam bahasa Arab (dalam bahasa Indonesia ditulis akidah).

Dengan demikian maka akidah dapat diartikan sebagai suatu keyakinan kuat yang tertanam di dalam hati terhadap adanya sang pencipta, yang mengatur alam beserta isinya serta rela menerima kebenaran dari ajaran Tuhan dalam menjalankan segala aktivitas kehidupan.

Sementara kata "akhlak" juga berasal dari bahasa Arab, yaitu [خلق] jamaknya [أخلاق] yang artinya tingkah laku, perangai tabi'at, watak, moral atau budi pekerti. Dalam Kamus Besar Bahasa Indonesia, akhlak dapat diartikan budi pekerti, kelakuan. Jadi, akhlak merupakan sikap yang telah melekat pada diri seseorang dan secara spontan diwujudkan dalam tingkah laku atau perbuatan. Jika tindakan spontan itu baik menurut pandangan akal dan agama, maka disebut akhlak yang baik atau akhlaqul karimah, atau akhlak mahmudah. Akan tetapi apabila tindakan spontan itu berupa perbuatanperbuatan yang jelek, maka disebut akhlak tercela atau akhlakul madzmumah.

\section{Pembentukan Akhlak}

Ada dua aliran yang membahas tentang pembentukan dan pembinaan akhlak, yaitu:

1) Akhlak tidak dapat dibentuk. Menurut aliran ini karena akhlak adalah instinct yang dibawa sejak lahir, dan akan timbul dengan sendirinya. Aliran ini berpendapat bahwa akhlak adalah pembawaan dari manusia sendiri, yaitu kecenderungan kepada kebaikan yang ada dalam diri manusia dan dapat juga berupa kata hati atau intuisi yang selalu cenderung kepada kebaikan dan kebenaran. Dengan demikian aliran ini memiliki pandangan bahwa akhlak akan tumbuh dengan sendirinya walaupun tanpa dibentuk oleh apapun. Karena akhlak adalah fitrahnya manusia dan tidak perlu dibentuk, namun akhlak tersebut ada yang baik dan ada yang buruk. Hal ini sejalan dengan perspektif Ibnu Thufail, jika akal tidak dipengaruhi oleh lingkungannya, niscaya akal akan mengesakan Tuhan dan akan menjalankan syariat Islam, akal akan mengatahui mana yang baik dan mana yang buruk.

2) Akhlak dapat dibentuk. Aliran ini berpendapat bahwa akhlak seseorang dapat dibentuk dengan alasan bahwa salah satu misi Nabi dan Rasul diutus adalah untuk membentuk akhlak manusia, dimana perilaku Nabi dan Rusul tersebut dapat dijadikan sebagai model atau contoh bagi umatnya. Sebagaimana dalam Al Qur'an surat ke 33 ayat 21 , bahwa, orang-orang yang menjadikan 


\section{Hasil Penelition}

Rasulullah sebagai uswatun hasanah itu adalah orang-orang yang selalu berharap rahmat Allah, dan selalu berharap pada hari pembalasan serta mereka banyak mngingat Allah. Sebaliknya orang-orang yang tidak berharap ramat Allah, tidak meyakini hari kiamat, sedikit mengingat Allah, maka seseorang itu tidak akan menjadikan Rasulullah sebagai uswatun hasanah. Pentingnya Nabi dan Rasul untuk mendidik manusia disebabkan manusia tidak akan mengetahui secara keseluruhan mana yang baik dan mana yang buruk. Oleh karena itu terbentuknya akhlak seseorang dapat dipengaruhi oleh contoh ataupun keteladanan yang didapatkan dari luar diri orang tersebut.

Dengan demikian akhlak seseorang dapat muncul dari dalam pribadi yang diwujudkan dalam bentuk perbuatan ataupun tindakan, yang tindakan tersebut merupakan cerminan dari sikap/perilaku seseorang dalam menentukan pilihan perbuatan. Dengan demikian akhlak yang baik dapat lahir bila pengetahuan dalam proses belajar mengajar dapat dipahami oleh peserta didik, sehingga mereka melakukan suatu tindakan berasaskan pada pengetahuan yang diperoleh dari proses pembelajaran. Demikian juga sebaliknya, akhlak yang buruk juga dapat muncul dalam tindakan/perbuatan. Hal ini dapat disebabkan karena kurangnya pengetahuan dalam memahami akibat perbuatan tersebut.

\section{Multiple Intelligences}

Multiple Intelligences yang dalam bahasa Indonesia diterjemahkan sebagai kecerdasan majemuk atau kecerdasan ganda merupakan salah satu teori kecerdasan yang memperoleh banyak pengakuan dalam dunia pendidikan. Pada awal mulanya (1970-an) Howard Gardner mengadakan riset dalam neoropsikologi dan psikologi perkembangan yang membawanya pada teori kecerdasan majemuk (multiple intelligences). Garisgaris besar teori ini dirampungkan pada tahun 1980an. Psikolog Howard Gardner memperkenalkan suatu teori kognitif baru yang dinamakannya teori "Multiple Intelligences", sebagai sebuah alternatif terhadap pendekatan lama yang menekankan hanya kecerdasan logis matematis. Teori ini mempertahankan suatu pandangan yang pluralistik mengenai pikiran, mengakui banyak aspek kognisi yang berlain-lainan yang memiliki kekhasan masingmasing, dan memandang setiap individu memiliki kekuatan-kekuatan kognitif yang berbeda-beda dan gaya-gaya kognitif yang tidak sama. Model Multiple Intelligences dilandaskan terutama pada temuantemuan mutakhir sains kognitif (yang mempelajari pikiran) dan neurosains (yang mempelajari otak).

Pada awal mulanya Howard Gardner, menemukan tujuh jenis kecerdasan tetapi kemudian mengembangkannya menjadi delapan, dan membahas kemungkinan kecerdasan yang ke sembilan. Kecerdasan-kecerdasan tersebut meliputi: 1) kecerdasan musikal, 2) kecerdasan kinestetik tubuh, 3) kecerdasan logis-matematis, 4) kecerdasan linguistik, 5) kecerdasan spasial, 6) kecerdasan interpersonal, 7) kecerdasan intrapersonal, 8) kecerdasan natural, 9) kecerdasan eksistensial.

\section{Sikap Keagamaan}

Secara hakiki manusia juga sebagai makhluk sosial. Manusia dilahirkan ke dunia dalam kondisi yang lemah dan tak berdaya. Dalam hidup bermasyarakat manusia saling berinteraksi, berbuat dan bertindak ataupun bersikap dengan menyesuaikan tempat lingkungan disekitarnya. Bagi ahli psikologi, sikap berakar pada alasan perbedaan individual yang berbeda dengan memperlihatkan tingkah laku dalam situasi yang berbeda pula. Sikap dipandang sebagai seperangkat reaksi-reaksi afektif terhadap objek-objek tertentu berdasarkan hasil penalaran, pemahaman dan penghayatan inividu. Sikap itu terbentuk dari hasil belajar dan pengalaman seseorang dalam hidupnya, sedangkan sikap yang ditampilkan seseorang adalah hasil dari proses berfikir, merasa dan pemilihan individu terhadap motif tertentu sebagai reaksi terhadap objek. Sikap dapat mencerminkan kepribadian seseorang, karena tingkah laku yang dilakukan olehnya merupakan perwujudan dari sikap yang dimilikinya. Menurut Chaplin, sebagaimana yang dikutib oleh Mohammad Asrori, mendefinisikan:"Sikap sebagai predisposisi atau kecenderungan yang relatif stabil dan berlangsung terus menerus untuk bertingkah laku atau bereaksi dengan suatu cara tertentu terhadap orang, lembaga, atau peristiwa, baik secara positif maupun negatif."

Dari pengertian sikap di atas, maka dapat disimpulkan sikap adalah suatu keadaan individu di dalam kesadarannya dalam berbuat ataupun bertindak yang dapat terjadi sekarang maupun yang akan datang. Aspek sikap tersebut di atas memberikan gambaran tentang proses sikap yang ada pada manusia, yang tentunya berbeda antara individu yang satu dengan individu yang lainnya dan saling berhubungan sehingga dapat melahirkan sikap yang dilakukan oleh manusia.

Sikap tentunya tidak terbentuk begitu saja, akan tetapi dipengaruhi oleh banyak faktor. Menurut Maxwell sebagaimana yang dikutib oleh Kaswan (2015), faktor-faktor yang dapat membentuk sikap antara lain adalah: 1) kepribadian atau watak Bawaan, 2) lingkungan, 3) sosialisasi, 4) teman sebaya dan kelompok bermain, 5) citra diri, 6) keterbukaan dan pengalaman baru, 7) pengaruh media, 8) penghargaan dan hukuman, 9) identifikasi model peran, 10) penampilan fisik, 11) pengaruh kultural, 12) pernikahan, keluarga, dan pekerjaan. 


\section{Hagil Penelition}

Metode Penelitian

Jenis dan Desain Penelitian

Jenis penelitian ini adalah mixed methods (penelitian campuran) kualitatif-kuantitatif, dengan sequential exploratory designs, yaitu pengumpulan data kualitatif dilakukan pertama kali dan dianalisis, kemudian data kuantitatif dikumpulkan dan dianalisis. Metode ini dengan bobot metode kualitatif lebih tinggi daripada kuantitatif (QUAL + quan). Penelitian kualitatif dalam penelitian ini mengarah pada penelitian lapangan (field research). Selain dari itu peneliti juga menggunakan kajian isi dokumen., dimana penggunaan dokumen ini berkaitan dengan apa yang disebut analisis isi. Cara menganalisis isi dokumen ialah memeriksa dokumen secara sistematik bentuk-bentuk komunikasi yang dituangkan secara tertulis dalam bentuk dokumen secara objektif. Kajian dalam penelitian kualitatif ini lebih mengarah pada studi deskriptif analisis, yaitu mendiskripsikan multidimensi dari berbagai hal yang terdapat dalam proses pembelajaran dengan berbasis multiple intelligences mata pelajaran akidah akhlak di Madrasah Aliyah Bengkulu Selatan.

Berdasarkan hasil analisis data kualitatif tersebut, kemudian dilanjutkan dengan analisis data kuantitatif dengan tujuan untuk memperkuat hasil analisis data kualitatif. Analisis data kuantitatif yang dilakukan adalah dengan menemukan korelasi dan regresi sebagai berikut: 1) Korelasi aversion therapy (X1) dengan sikap keagamaan (Y), korelasi modelling (X2) dengan sikap keagamaan (Y), korelasi aversion therapy (X1) dengan modelling (X2), serta korelasi ganda aversion therapy (X1) dan modelling (X2) dengan sikap keagamaan (Y). 2) Regresi aversion therapy (X1) terhadap sikap keagamaan (Y), regresi modelling (X2) terhadap sikap keagamaan $(\mathrm{Y})$, regresi aversion therapy (X1) terhadap modelling (X2), serta regresi ganda aversion therapy (X1) dan modelling (X2) terhadap sikap keagamaan (Y).

Adapun penelitian kuantitatif ini mengarah pada dampak multidimensional pembelajaran akidah akhlak berbasis multiple intelligences melalui metode aversion therapy dan modelling dalam pelaksanaan pembelajaran. Sehingga diketahui seberapa besar dampak metode tersebut dalam pelaksanaan pembelajaran dan bagaimana sikap keagamaan siswa madarsah aliyah setelah diterapkannya.

\section{Pendekatan Penelitian}

Penelitian ini menggunakan pendekatan fenomenologis, pendekatan kuantitatif dan pendekatan komparatif. Pendekatan fenomenologis lebih mendiskripsikan fenomena yang terjadi di lapangan, khususnya pada pembelajaran akidah akhlak yang meliputi perencanaan, pelaksanaan dan hasil belajar siswa Madrasah Aliyah Bengkulu Selatan.
Selanjutnya peneliti menggunakan pendekatan kuantitatif dengan analisis statistik, dimana analisis statistik tersebut menggunaka korelasi dan regresi untuk mengetahuai pandangan siswa terhadap aversion therapy, modelling, dan sikap keagamaan. Sedangkan pendekatan komparatif dimana peneliti membandingkan sehingga diketahui persamaan dan perbedaan dari fenomena yang diamati yakni multidimensi pembelajaran akidah akhlak dan dampaknya bagi sikap keagamaan siswa pada MAN Bengkulu Selatan, MA Al Quraniyah Bengkulu Selatan, dan MA Makrifatul Ilmi Bengkulu Selatan.

\section{Social Situation dan Tahapan Penelitian}

Penelitian ini mulai dilaksanakan sejak tanggal 6 Juni 2016 sampai dengan 18 September 2017. Adapun social situation (situasi sosial) dalam penelitian ini meliputi tiga hal yaitu:

\section{1) Place (Tempat).}

Tempat penelitian ini adalah Madrasah Aliyah Negeri Bengkulu Selatan, Madrasah Aliyah al-Quraniyah Bengkulu Selatan, dan Madrasah Aliyah Makrifatul 'Ilmi Bengkulu Selatan. Pertimbangan memilih lokasi penelitian yang bertempat pada Madrasah Aliyah Negeri Bengkulu Selatan, bahwasanya madrasah ini adalah madrasah tertua di propinsi Bengkulu. Sebagai madrasah yang pertama kali ada di propinsi Bengkulu, seharusnya dapat lebih baik dan lebih maju dari madrasah ataupun sekolah yang lain. Namun ternyata madrasah ini jauh tertinggal dan semakin hilang eksistensinya. Sedangkan pertimbangan memilih Madarsah Aliyah al-Quraniyah Bengkulu Selatan, karena madrasah ini merupakan bagian dari pondok pesantren AlQuraniyah Bengkulu Selatan, namun keadaannya jauh lebih tertinggal dan menurun dibandingkan dengan madrasah yang lainnya. Adapun pertimbangan memilih madrasah Aliyah Makrifatul 'Ilmi, dengan pertimbangan madrasah Aliyah ini adalah madrasah swasta dan terbaru yang ada di kabupaten Bengkulu Selatan, tetapi cukup berkembang pesat.

\section{2) Actor (orang)}

Actor/orang dalam penelitian ini meliputi orang-orang yang dapat membantu peneliti untuk mengadakan penelitian terhadap permasalahan yang diangkat. Actor tersebut meliputi: 1) kepala Madrasah Aliyah Negeri Bengkulu Selatan, kepala Madrasah Aliyah Makrifatul 'Ilmi, dan kepala Madrasah Aliyah Al Quraniyah Bengkulu Selatan, 2) guru pendidikan akidah akhlak, guru bimbingan konseling (BK), dan guru pembina keagamaan, serta para siswa pada madrasah tersebut. Adapun siswa dalam penelitian ini yang peneliti gunakan sebagai subyek penelitian adalah siswa Madrasah Aliyah Negeri Bengkulu Selatan dengan pertimbangan bahwa siswa madrasah ini memiliki jumlah siswa 


\section{Hagil Penelition}

lebih banyak dibandingkan dengan madrasah lainnya di Bengkulu Selatan.

\section{3) Activity/aktivitas}

Aktivitas yang dimaksud dalam situasi sosial pada penelitian ini adalah bagaimana proses kegiatan belajar mengajar di dalam kelas dan sikap siswa dalam mengikuti proses belajar mengasjar tersebut. Selain itu juga aktivitas dalam penelitian ini adalah sikap keagamaan siswa di dalam lingkungan Madrasah Aliyah Bengkulu Selatan.

Adapun tahapan yang dilakukan peneliti adalah sebagai berikut:

\section{Populasi dan Sampel}

Populasi dalam penelitian ini meliputi seluruh wilayah generalisasi yang terdiri atas: obyek/subyek yang mempunyai kualitas dan karakteristik tertentu yang ditetapkan oleh peneliti untuk dipelajari dan kemudian ditarik kesimpulannya." Populasi dalam penelitian ini adalah seluruh guru akidah akhlak dan siswa pada Madrasah Aliyah Bengkulu Selatan.

\section{Teknik Pengambilan Sampel}

Sampel dalam penelitian kualitatif dipilih secara purposive sampling dimana peneliti mempertimbangkan dan menentukan siapa saja yang dianggap paling tahu tentang apa yang peneliti butuhkan. Selain itu penelitian ini bersifat snowball sampling, yaitu sampel yang semulanya sedikit, lama kelamaan akan menjadi besar sesuai dengan data yang dibutuhkan peneliti. Sedangkan dalam penelitian kuantitatif, metode yang digunakan adalah dengan teknik Probability Sampling, dimana teknik pengambilan sampel yang memberikan peluang yang sama bagi setiap unsur (anggota) populasi untuk dipilih menjadi anggota sampel. Jenis yang digunakan adalah cluster random sampling. Teknik ini merupakan kelompok individu (cluster) dari subjek-subjek penelitian. Hal ini berarti sampel penelitian ini menggunakan kelompok-kelompok kelas. Sampel dalam penelitian ini mengambil jumlah dari populasi yang ada di MAN Bengkulu Selatan yang berjumlah 199 siswa. Pengambilan sampel mengacu pada pendapat Arikunto yang dikutip oleh Riduwan, menyatakan bahwa: "Untuk sekedar ancer-ancer, maka apabila subyek kurang dari 100, maka lebih baik diambil semua, sehingga penelitiannya dinamakan penelitian populasi. Selanjutnya jika subyeknya besar, dapat diambil 10\%-15\%, atau 20\%-25\%." Dengan demikian 20\% X $199=39$ siswa yang peneliti ambil sebagai sampel, yakni kelas XII IPS 1, XII IPS 2, dan XII IPS 3 pada Madarsah Aliyah Negeri Bengkulu Selatan. Pada Madarsah Aliyah Makrifatul Ilmi Bengkulu Selatan, jumlah siswa secara keseluruhan adalah 26 siswa, sehingga seluruh siswa diambil menjadi sampel penelitian. Demikian juga halnya pada Madrasah Aliyah Al Quraniyah, jumlah siswa secara keseluruhan adalah 24 siswa, yang seluruhnya peneliti ambil sebagai sampel.

\section{Variabel Penelitian}

Independent Variable sering diartikan dengan variabel bebas. Variabel bebas adalah variabel yang menentukan arah atau perubahan tertentu pada variabel tergantung, sementara variabel bebas berada pada posisi yang lepas dari "pengaruh" variabel tergantung. Dalam penelitian ini yang menjadi Independent Variable variabel bebas adalah pandangan siswa tentang aversion therapy (Variabel $\mathrm{X}_{1}$ ) dan pandangan tentang modelling (Variabel $\mathrm{X}_{2}$ ). Aversion therapy merupakan suatu metode yang peneliti gunakan dalam proses pembelajaran akidah akhlak, dimana metode ini bertujuan merangsang otak siswa sebagai hukuman atas perlakuan yang tidak baik. Sedangkan modeling adalah contoh sikap baik yang dilakukan oleh siswa minimal untuk dirinya sendiri dan juga siswa lainnya. Dalam penelitian ini pandangan siswa tentang metode aversion therapy dan modeling dinyatakan dengan skor yang diperoleh berdasarkan angket.

Dependent Variable sering diartikan dengan variabel tergantung. Variabel tergantung adalah variabel yang "dipengaruhi" oleh variabel bebas. Dalam penelitian ini yang menjadi variabel Dependent Variable atau variabel tergantung adalah sikap keagamaan siswa (Variabel Y). Adapun sikap keagamaan siswa meliputi sikap dalam berbuat dan berperilaku di madrasah dan sikap dalam menjalankan ajaran agama terutama sholat dhuhur dan sholat sunnah dhuha serta kegiatan keagamaan lainnya.Dalam penelitian ini pandangan siswa tentang metode aversion therapy dan modeling dinyatakan dengan skor yang diperoleh berdasarkan angket.

\section{Hipotesis}

Dalam penelitian kuantitatif diperlukan adanya hipotesis penelitian. Hipotesis ini berfungsi untuk menjawab rumusan masalah yang ke tiga dalam penelitian ini. Adapun hipotesis yang peneliti kemukakan adalah sebagai berikut:

1. Ada hubungan antara metode Aversion Therapy dan Modelling dengan Sikap Keagamaan Siswa MA Bengkulu Selatan

2. Tidak ada hubungan antara metode Aversion Therapy dan Modelling dengan Sikap Keagamaan Siswa MA Bengkulu Selatan

3. Ada pengaruh metode Aversion Therapy dan Modelling terhadap Sikap Keagamaan Siswa MA Bengkulu Selatan

4. Tidak ada pengaruh metode Aversion Therapy dan Modelling terhadap Sikap Keagamaan Siswa MA Bengkulu Selatan.

\section{Instrumen Pengumpulan Data}


Pengumpulan data dilakukan dengan observasi, wawancara, dan dokumentasi serta angket Hal ini dilakukan karena peneliti berfikir bahwa dengan instrument tersebut, data yang dihasilkan sudah mencukupi dan dapat lebih lengkap serta akurat.

\section{Teknik Analisis Data}

\section{Analisis Data Kualitatif}

Proses analisis data dalam penelitian ini dimulai dengan menelaah seluruh data yang tersedia dari berbagai sumber, yaitu dari observasi, wawancara, dan dokumentasi, dan juga pengamatan yang sudah dituliskan dalam catatan lapangan, dokumen pribadi, dokumen resmi, gambar, foto, dan sebagainya. Setelah dibaca, dipelajari, dan ditelaah, langkah berikutnya ialah ialah mengadakan reduksi data yang dilakukan dengan jalan abstraksi. Abstraksi merupakan usaha membuat rangkuman yang inti, proses, dan pernyataan-pernyataan yang perlu dijaga sehingga tetap berada di dalamnya. Langkah selanjutnya adalah menyusunnya dalam satuan-satuan. Satuan-satuan itu kemudian dikatagorisasikan dan dipilah berdasarkan jenisnya. Setelah menganalisa data kemudian dilanjutkan dengan keabsahan data kualitatif yaitu dengan cara triangulasi. Dan dilanjutkan dengan display data/penyajian data.

Analisis data kualitatif ini dimaksudkan untuk menjawab rumusan masalah mengenai sikap keagamaan siswa Madrasah Aliyah Bengkulu Selatan pada umumnya dan juga rumusan masalah mengenai multidimensional pembelajaran akidah akhlak berbasis multiple intelligences di Madrasah Aliyah Bengkulu Selatan.

\section{Analisis Data Kuantitatif}

Proses analisis data kuantitatif di awali dengan menaikkan data ordinal menjadi data interval atau mengolah data mentah menjadi data baku. Adapun tujuannya adalah data-data statistik yang diperoleh umumnya masih acak "mentah" dan tidak terorganisisr dengan baik (raw data). Data-data tersebut harus diringkas dengan baik dan teratur dalam bentuk tabel atau presentasi grafis, sebagai dasar untuk berbagai pengambilan keputusan (Statistik Inferasial).

Setelah data baku diperoleh, langkah selanjutnya adalah melakukan uji persyaratan analisis berupa uji normalitas dan uji homogenitas. Dalam analisis data kuantitatif dalam penelitian ini, peneliti tidak menggunakan uji homogenitas, karena uji homogenitas hanya digunakan pada uji parametris yang menguji perbedaan antara kedua kelompok atau beberapa kelompok yang berbeda subyeknya atau sumber datanya. Sedangkan penelitian ini menggunakan uji parametris regresi linear, sehingga homogenitas tidak diperlukan, sebab uji regresi linear tidak menguji perbedaan beberapa kelompok.

\section{Hagil Penelition}

Adapun uji normalitas dalam analisis data kuantitatif ini menggunakan metode kolmogrov-Smirnov dengan bantuan SPSS.16.0, pengolahan data Analyze, Regression, Linear. Dasar pengambilan dalam uji normalitas yakni: jika signifikansi lebih besar dari 0.05, maka data tersebut berdistribusi normal. Sebaliknya, jika nilai signifikansi lebih kecil dari 0.05 , maka data tersebut tidak berdistribusi normal. Untuk mengetahuai kontribusi pembelajaran akidah akhlak terhadap sikap keagamaan siswa dilakukan uji korelasi dan regresi. Analisis korelasi digunakan untuk melihat apakah ada hubungan antara sikap keagamaan dengan pembelajaran akidah akhlak. Jika ada hubungan, seberapa kuat hubungan antara variabel tersebut. keeratan tersebut dinyatakan dengan nama koefisien korelasi bivariate/pearson product moment. Selanjutnya analisis regresi digunakan dengan tujuan untuk peramalan dimana dalam model ini terdapat variabel dependent dan independent. Jika ada peningkatan satu variabel, apakah variabel lain akan mengikuti atau tidak. Dalam analisis regresi ini akan melihat apakah jika terjadi peningkatan dalam penerapan metode aversion therapy dan modeling, disertai pula peningkatan terhadap kualitas belajar dan sikap keagamaan siswa Madrasah Aliyah Bengkulu Selatan.

\section{Hasil Penelitian}

\section{Sikap Keagamaan Siswa Madrasah Aliyah Bengkulu Selatan}

Berdasarkan hasil observasi terhadap sikap siswa MAN Bengkulu Selatan, maka peneliti menemukan masih banyak penyimpangan dan pelanggaran yang dilakukan oleh para siswa, diantaranya adalah masih ada para siswa yang lebih suka menghabiskan waktu mereka dengan bermain bersama. Beberapa siswa senang merokok bersama setelah pulang sekolah. Sholat Zuhur dan Jum'at di madrasah harus selalu diperintah dan diperingatkan, akibatnya mushola madrasah menjadi sepi dari jamaah sholat dhuhur, hanya beberapa orang siswa saja yang ada kesadarannya untuk menunaikannya, apalagi melaksanakan sholat lima waktu di rumah. Selain dari itu masih banyaknya siswa MAN Bengkulu Selatan yang belum bisa membaca Al Quran. Berdasarkan data dokumentasi pembina agama tercatat 54 siswa yang belum bisa membaca Al Qur'an tahun 2016/2017. Hal ini diperparah lagi dengan beberapa siswa yang jarang masuk sekolah ataupun membolos, malas belajar serta melakukan pelanggaran tata tertib sekolah lainnya.

Bila dilihat dari latar belakang keadaan siswa, beberapa siswa yang memilih masuk ke Madrasah Aliyah ini karena tidak diterima di sekolah lain, dengan berprinsip daripada mereka tidak bersekolah atau bersekolah di swasta, lebih baik mereka sekolah di Madrasah Aliyah ini. Ada diantara mereka yang memiliki latar belakang memilih 
masuk pada Madrasah Aliyah karena atas anjuran orang tua, atau karena ikut-ikutan teman. Selain dari itu beberapa diantara mereka karena tidak percaya diri dengan hasil belajar yang mereka dapatkan sewaktu menempuh ujian akhir di Sekolah Tingkat Pertama (SLTP). Sehingga wajarlah bila watak dan perilaku para siswa banyak yang menyimpang dari harapan yang diinginkan, serta tingkat intelektual peserta didiknya agak rendah karena siswanya merupakan saringan dari Sekolah Menengah Negeri yang ada di Bengkulu Selatan, sehingga pelaksanaan pembelajaran terkadang banyak mengalami kesulitan dan hambatan.

Selain dari itu latar belakang siswa masuk

pada Madrasah Aliyah Bengkulu Selatan dikarenakan juga atas anjuran orang tua ataupun karena kesadaran mereka sendiri untuk memilih Madrasah Aliyah ini sebagai tempat yang paling tepat dalam menuntut ilmu, baik ilmu pengetahuan umum maupun ilmu pengetahuan agama Islam. Mereka juga berkeyakinan bahwa dengan menuntut ilmu pada Madrasah Aliyah Negeri Bengkulu Selatan dapat mengantarkan mereka pada tingkat dan jenjang keilmuan yang lebih tinggi, baik ilmu pengetahuan umum maupun ilmu-ilmu agama. Dengan demikian keberadaan siswa Madrasah Aliyah Negeri Bengkulu Selatan ini sangat majemuk dengan latar belakang yang beragam pula.

Demikian juga halnya dengan proses pembelajaran di kelas, khususnya mata pelajaran Akidah Akhlak. Pendidikan Akidah Akhlak merupakan satu diantara mata pelajaran yang terdapat dalam kurikulum Madrasah Aliyah Negeri Bengkulu Selatan. Pendidikan Akidah Akhlak bertujuan agar para siswa memiliki kepribadian dan akhlak yang baik yang berlandaskan pada nilai dan ajaran agama Islam. Dalam proses pembelajaran tersebut, bahwasanya guru mata pelajaran Akidah Akhlak sudah berusaha untuk menyampaikan materi pelajaran dengan baik, agar pelajaran tersebut dapat ditangkap, dan mudah untuk dipahami oleh siswa dengan baik.

Namun demikian dalam pelaksanaan pembelajaran Akidah Akhlak di Madrasah Aliyah Negeri Bengkulu Selatan, masih banyak siswa yang kurang tanggap selama proses pembelajaran berlangsung. Diantaranya adalah masih ada siswa yang melamun, cuek, asyik dengan pekerjaan sendiri, berbicara dengan teman lainnya, ataupun tidur, sehingga mereka tidak dapat memahami dan mengerti dari pembelajaran yang telah dilaksanakan. Selain dari itu mereka juga beranggapan bahwa mata pelajaran Akidah Akhlak tidak begitu penting, karena mata pelajaran ini tidak diikutkan dalam ujian nasional. Bila sudah demikian, maka wajarlah mereka memiliki sikap yang kurang baik, karena mereka kurang memahami akan pentingnya pelajaran Akidah Akhlak.
Selain dari hal tersebut di atas, berdasarkan hasil wawancara dan dokumentasi kepada guru BP menyatakan bahwa, kurun waktu satu semester terakhir (Juli 2016 - Februari 2017), pada kelas X terdapat 25 kasus berat. Sedangkan kelas XI terdapat 59 kasus berat, dan kelas XII terdapat 29 kasus pelanggaran berat yang penanganannya tidak bisa lagi dilakukan oleh guru piket dan wali kelas.. Jumlah seluruhnya pada semester ini yaitu 3 jenis pelangaran berat siswa. Diantara pelanggaran berat tersebut adalah berkelahi, merokok, berpacaran di sekolah, absen kehadiran (alpa), bolos, mencuri, dan lain-lain. Penanganannya telah dilakukan bimbingan individu, surat perjanjian disertai panggilan orang tua. Bahkan ada yang dikeluarkan yakni berjumlah 3 orang. Hal di atas merupakan kasus berat dan belum termasuk kasus ringan. Faktor-faktor yang menjadi penyebab banyaknya pelanggaran siswa antara lain adalah lingkungan pergaulan diluar madrasah yang kurang mencerminkan nuansa islami, lingkungan keluarga yang kurang mendukung, kurangnya perhatian orang tua dan guru, kurangnya pengetahuan agama pada siswa, pembelajaran yang kurang menarik sehingga menyebabkan siswa merasa bosan dan tidak mau belajar, dan masih banyak yang lainnya.

Sikap keagamaan siswa Man Bengkulu Selatan tersebut di atas sedikit berbeda dengan sikap keagamaan siswa MA Marifatul Ilmi Bengkulu Selatan. Adapun rekap hasil wawancara dengan guru BK MA Makrifatul Ilmi Bengkulu Selatan jelaslah bahwa sikap keagamaan siswa MA Makrifatul Ilmi Bengkulu Selatan berbeda jauh dengan sikap keagamaan siswa MAN Bengkulu Selatan. Dimana pada umumnya siswa MA Makrifatul Ilmi Bengkulu Selatan berlaku sopan dalam kesehariannya, baik dilingkungan madrasah maupun diluar madrasah. Demikian juga halnya dengan bentuk pelanggaran yang paling sering dilakukan oleh siswa MA Makrifatul Ilmi Bengkulu Selatan, yaitu berkenaan dengan kegiatan belajar mengajar seperti setoran tahfiz (hafalan AL Quran) banyak yang terlambat, dan tidak sesuai dengan target yang telah ditentukan, sehingga diperlukan langkah-langkah penyelesaian siswa yang bermasalah tersebut dengan pembimbingan lebih terhadap siswa yang belum tuntas masalah tahfiz tersebut. sedangkan pada siswa yang bermasalah penyelesaiannya adalah dengan diberi pengarahan dan masukan terhadap siswa yang bermasalah tersebut.

Sikap keagamaan siswa MA Al Quraniyah Bengkulu Selatan tidak jauh berbeda dengan sikap keagamaan MA Makrifatul Ilmi Bengkulu Selatan. Dimana MA Alquraniyah Bengkulu Selatan ini juga merupakan bagian dari pondok pesantren $\mathrm{Al}$ Quraniyah, dan dibawah naunya yaysan Affan. Sikap keagamaan siswa di dalam pondok pesantren tentunya sangat diperhatikan dan selalu terawasi. Terutama yang berkenaan dengan pelaksanaan sholat 
lima waktu secara berjamaah dan kegiatan-kegiatan lainnya. Karena lingkungan pondok yang sangat mendukung terbentuknya akhlak yang baik, dengan sendirinya siswa terbiasa untuk bersikap yang baik pula.

Dengan demikian dapat disimpulkan bahwa sikap keagamaan siswa Madrasah Aliyah Negeri Bengkulu Selatan pada umumnya belum mencerminkan nuansa keagamaan. Karena lingkungan madrasah yang belum optimal sepenuhnya dalam mendukung program keagamaan. Sedangkan sikap keagamaan siswa MA Makrifatul Ilmi Bengkulu Selatan dan MA Al Quraniyah Bengkulu Selatan telah baik. Dimana siswanya bersikap sopan dan santun dalam kesehariannya baik dilingkungan madrasah maupun diluar madrasah. Hal ini dapat disebabkan karena siswa MA Makrifatul Ilmi dan MA Al Quraniyah Bengkulu Selatan berada dalam lingkungan pondok pesantren. Sehingga nuansa keagamaan benar-benar diterapkan dan dilaksanakan dengan baik.

\section{Dimensi Pembelajaran Akidah Akhlak Tingkat Madrasah Aliyah. \\ Komponen RPP \\ Bila dilihat dari seluruh RPP Akidah Akhlak} Madrasah Aliyah Bengkulu Selatan yang berjumlah 20 , yang terdiri dari RPP kelas X yang berjumlah 10 , dan RPP kelas XI yang berjumlah 10. Setelah diperiksa semuanya ternyata masih ada komponen RPP yang tidak lengkap. Kekurangan tersebut karena tidak dicantumkannya metode pembelajaran, pemilihan sumber belajar, pemilihan media belajar, dan model belajar. Demikian juga dengan RPP Akidah Akhlak MA Al Quraniyah Bengkulu Selatan yang berjumlah 20 RPP. Masih ada komponennya yang tidak lengkap yaitu tidak dicantumkannya metode pembelajaran, pemilihan sumber belajar, pemilihan media belajar, dan model belajar. Hal ini sedikit berbeda dengan RPP Akidah Akhlak MA Makrifatul 'Ilmi. Bengkulu Selatan. Dari 20 RPP yang diteliti yakni RPP Akidah Akhlak Kelas X berjumlah 10, dan RPP Akidah Akhlak Kelas XI berjumlah 10. Setelah diperiksa dari 20 RPP tersebut, ternyata semuanya tidak lengkap. Hal ini dikarenakan RPP MA Makrifatul 'Ilmi masih menggunakan KTSP dan belum K13. Adapun komponen yang tidak ada dalam RPP tersebut yaitu kompetensi inti, Indikator pencapaian kompetensi, media pembelajaran, dan model pembelajaran. Dengan demikian dapat disimpulkan bahwa, dari seluruh RPP mata pelajaran Akidah Akhlak di Madrasah Aliyah Bengkulu Selatan, baik RPP mata pelajaran Akidah Akhlak Madrasah Aliyah Negeri Bengkulu Selatan maupun RPP mata pelajaran Akidah Akhlak MA Makrifatul 'Ilmi Bengkulu Selatan, dan RPP MA Al Quraniyah Bengkulu Selatan, semuanya belum memiliki komponen yang lengkap.

\section{Perumusan Indikator Pencapaian Kompetensi}

a. Keterkaitan antara KI 1 dengan kompetensi dasar. Pada aspek ini seluruh RPP memiliki keterkaitan antara KI 1 dan kompetensi dasar. Hal ini disebabkan KI 1 memuat kalimat secara umum yaitu "Menghayati dan mengamalkan ajaran agama yang dianutnya". Dengan demikian setiap unsur kompetensi dasar dalam RPP memuat dan mencantumkan pengahayatan dan pengamalan ajaran agama Islam. Dari 60 RPP yang dianalisis terdapat 40 RPP yang memiliki keterkaitan antara Kompetensi Inti (KI 1) dengan kompetensi dasar. Sedangkan 20 RPP lainnya tidak memiliki Kompetensi Inti (KI 1), karena RPP ini masih memakai KTSP yakni RPP MA Makrifatul Ilmi Bengkulu Selatan.

b. Menunjukkan pencapaian hasil belajar peserta didik secara utuh (kognitif, afektif, dan psikomotorik). Pada dasarnya seluruh RPP yang dianalisis telah memiliki ranah kognitif, afektif dan psikomotorik. Namun demikian terdapat 20 RPP yang belum menunjukkan pencapaian kompetensi belajar peserta didik secara utuh. Hal ini dikarenakan dalam kegiatan inti pembelajaran siswa hanya berdiskusi dan mempresentasikan hasil diskusi tersebut dan belum pada tarap pendalaman materi yang berkelanjutan.

\section{Pemilihan Materi Ajar}

Dari seluruh RPP yang dianalisis, pemilihan materi ajar dipilih telah berdasarkan pada tujuan pembelajaran dan kompetensi yang akan dicapai. Demikian juga halnya tingkat keluasan dan kedalaman materi telah disesuaikan dengan karakteristik peserta didik (termasuk yang cepat dan lambat, motivasi tinggi dan rendah). Selanjutnya penataan materi juga telah disesuaikan dengan karakteristik mata pelajaran, dan keluasan dan kedalaman materijuga memungkinkan Akidah Akhlak dalam waktu yang disediakan, dan telah sesuai dengan fakta, konsep, dan prinsip serta keruntutan uraian materi ajar.

\section{Pemilihan Metode Pembelajaran}

Dari seluruh RPP yang dianalisis, semuanya materi dipilih berdasarkan tujuan pembelajaran atau kompetensi yang akan Akidah Akhlak. Demikian juga dengan tingkat keluasan dan kedalaman materi telah disesuaikan dengan karakteristik peserta didik (termasuk yang cepat dan lambat, motivasi tinggi dan rendah). Tidak berbeda halnya dengan penataan materi yang telah disesuaikan dengan karakteristik mata pelajaran. Sedangkan keluasan dan kedalaman materi memungkinkan Akidah Akhlak dalam waktu yang disediakan, dan juga sesuai dengan fakta, konsep, dan prinsip, serta keruntutan uraian materi ajar.

Berkaitan dengan hal tersebut di atas, terdapat 40 RPP yang tidak mencantumkan metode 
pembelajaran secara terpisah. Namun demikian 40 RPP tersebut telah ada atau dimasukkan secara langsung pada kegiatan pembelajaran yakni dalam persiapan pembelajaran. Sedangkan 20 RPP lainnya mencantumkan metode pembelajaran secara terpisah, sehingga jelas terlihat dalam RPP tersebut metode pembelajaran yang akan digunakan.

\section{Pemilihan Media Pembelajaran}

Pada dasarnya seluruh RPP telah memilih media pembelajaran sesuai dengan tujuan pembelajaran, dan media belajar dipilih dengan materi pembelajaran yang sesuai. Selain itu juga tentunya media belajar dipilih menggunakan pendekatan saintifik serta terdapat kesesuaian dengan karakteristik siswa. Namun dari 60 RPP yang dianalisis peneliti, terdapat 20 RPP yang tidak mencantumkan media pembelajaran secara terpisah. Media pembelajaran tersebut dipaparkan dalam persiapan kegiatan pembelajaran. Sedangkan 24 RPP lainnya mencantumkan dengan jelas media pembelajaran yang akan dipakai.

\section{Model Pembelajaran}

Model Pembelajaran. Dalam aspek ini ada 2 bagian yakni, 1) Kesesuaian dengan tujuan pembelajaran, 2) Kesesuaian dengan karakteristik materi. Dari seluruh RPP yang dianalisis peneliti tidak mencantumkan model pembelajaran yang dipakai secara terpisah. Namun demikian terdapat 40 RPP yang memaparkan model pembelajaran yang digunakan dalam kegiatan persiapan pelaksanaan pembelajaran. Sedangkan 20 RPP lainnya tidak mencantumkan model pembelajaran yang akan digunakan.

\section{Skenario Pembelajaran \\ Dari 60 RPP yang dianalisis, semuanya} telah memiliki kesesuaian antara scenario pembelajaran dengan pendekatan saintifik (5M). demikian juga halnya kegiatan pembelajaran telah sesuai dengan prinsip Akidah Akhlak, dan juga kegiatan pembelajaran dengan sistematika /keruntutan Materi. Selain dari itu alokasi waktu juga disesuaikan dengan rincian pengorganisasian. Namun demikian berbeda dengan metode pembelajaran, dimana terdapat 40 RPP yang hanya menggunakan metode diskusi dalam pembelajaran dan juga tidak mencantumkan metode pembelajaran tersebut secara terpisah. Demikian juga halnya langkah-langkah dengan model pembelajaran yang mencantumkan model pembelajaran pada kegiatan persiapan pelaksanaan pembelajaran.

\section{Rancangan Penilaian}

Dari 60 RPP yang telah dianalisis oleh peneliti, seluruh RPP telah disusun dan memiliki aspek yakni adanya kesesuaian bentuk, teknik dan instrumen dengan penilaian autentik (tertulis, lisan, produk, projek, pengamatan, dan penilaian diri), adanya kesesuaian dengan indikator, adanya kesesuaian antara bentuk, teknik, dan instrument penilaian sikap, adanya kesesuaian antara bentuk, teknik, dan instrument penilaian pengetahuan, adanya kesesuaian antara bentuk, teknik, dan instrument penilaian keterampilan. Namun demikian terdapat 26 RPP yang tidak memiliki adanya kesesuaian kunci jawaban (pada tes tertulis, lisan) dengan soal, dan adanya kesesuaian pedoman penskoran dengan soal. Hal ini disebabkan 26 RPP tersebut tidak ditemukan kunci jawaban dan juga pedoman penskoran. Sedangkan 14 RPP lainnya telah lengkap sebagaimana yang dimaksud di atas. Berdasarkan hasil analisis yang telah peneliti lakukan terhadap seluruh RPP Madrasah Aliyah Bengkulu Selatan, baik RPP yang berasal dari Madrasah Aliyah Negeri Bengkulu Selatan maupun RPP yang berasal dari Madrasah Aliyah Makrifatul Ilmi Bengkulu Selatan, dan RPP MA Al Quraniyah Bengkulu Selatan, maka dapat disimpulkan bahwa seluruh RPP tersebut belum memenuhi standar yang telah ditetapkan sesuai dengan Permendikbud RI no. 22. Tahun 2016 tentang standar Proses Pendidikan Dasar dan Menengah.

\section{Sikap Siswa Dalam Proses Belajar Mengajar}

Kegiatan pembelajaran di dalam kelas nampak lebih bersemangat dari sebelumnya setelah metode aversion therapy ini diterapkan. Perubahan perilaku peserta didik jauh lebih baik dari sebelumnya. Mereka lebih bersemangat dalam mengamati tayangan film/visual yang disajikan. Hal ini merupakan dampak positif dari therapy yang dilakukan kepada peserta didik selama pembelajaran. Bila sebelumnya guru yang lebih aktif, maka dalam pelaksanaan pembelajaran dengan tayangan film justru siswa yang lebih aktif. Tidak nampak siswa yang ribut atau main dengan temannya. Tidak nampak juga siswa acuh tak acuh ataupun tidur di dalam kelas. Tidak ada juga siswa yang keluar masuk kelas dengan alasan mau ke toilet dan sebagainya. Semuanya nampak serius sekali memperhatikan tayangan film/visual pembelajaran. Pembelajaran seperti ini sungguh menarik perhatian bagi mereka. Perubahan sikap dalam proses belajar mengajar tersebut menunjukkan bahwasanya materi yang diberikan pada peserta didik mudah untuk dimengerti dan dipahami, dan selanjutnya berangsur-angsur diterapkan dalam perbuatan keseharian.

\section{Sikap Keagamaan Siswa di Lingkungan Madrasah}

Proses pelaksanaan pembelajaran Akidah Akhlak di kelas sangatlah mendukung pada sikap keagamaan siswa di luar kelas. Bila siswa mudah mengerti, memahami pelajaran yang diberikan, maka secara berangsur-angsur akan mudah pula untuk diterapkan dalam sikap dan perbuatan keseharian. 
Hal ini nampak adanya perubahan sikap siswa kearah yang lebih baik. Dimulai dari hal yang sederhana, beberapa siswa sudah mulai melaksanakan dan membudayakan senyum, sapa dan salam (3S). ketika memasuki kelas atau kantor dewan guru dan tata usaha, mereka sudah mengucapkan salam dan bersalaman dengan bapak ataupun ibu guru. Begitu juga dengan sikap siswa terhadap kegiatan keagamaan lainnya, seperti pembacaan surat-surat pendek sebelum proses belajar mengajar dilaksanakan. Sebelumnya siswa masih malas dan enggan dalam mengikuti kegiatan tersebut, namun secara berangsur-angsur, siswa sudah mulai memahami manfaat yang dapat diambil dari kegiatan tersebut. siswa lebih antusias dan semangat dalam mengikuti pembacaan surat-surat pendek. Karena setiap hari dilakukan, akhirnya siswa menjadi terbiasa melakukannya.

Untuk memperkuat sikap keagamaan siswa tersebut, selain melakukan therapy dan home work kepada siswa, dilakukan juga metode modelling kepada setiap siswa. Modelling awal mulanya diterapkan kepada siswa yang telah memiliki akhlak yang baik, dan diutamakan siswa yang menjadi peringkat/juara kelas. Siswa tersebut dipilih dan diberikan penjelasan tentang sikap dan perilaku yang seharusnya dilakukan yakni sebagai contoh terutama dalam bersikap dan selalu mengajak kearah kebaikan. Selanjutnya siswa diberikan surat pernyataan dan ditandatangani bila siswa yang dipilih sebagai modelling tersebut bersedia dan telah paham serta mengerti akan tugas yang diberikan dan dibebankan kepadanya. Modelling ini dilakukan sebagai contoh sikap yang baik yang ditunjukkan ataupun dilakukan oleh siswa sehingga siswa lain yang melihatnya secara langsung akan terpengaruh oleh perbuatan temannya. Selanjutnya siswa yang ditunjuk sebagai modelling akan berangsur-angsur dan berupaya untuk merubah sikap dirinya kearah yang lebih baik, karena ia berusaha memberikan contoh yang baik kepada teman-temannya. Pada akhirnya setiap siswa menjadi model bagi dirinya sendiri dan juga bagi teman-temannya, sehingga peningkatan sikap keagamaan kearah yang lebih baik benar-benar terwujud.

Selain dari itu perubahan yang nampak sangat jelas setelah diterapkannya aversion therapy dan modelling ini adalah sikap keagamaan siswa sudah mulai meningkat dari sebelumnya. Kegiatan sholat dhuha secara bergiliran sudah mulai nampak berjalan kembali. Demikian juga halnya dengan sholat dhuhur berjamaah di musholla masjid, siswa sudah mulai berangsur-angsur menunaikannya walaupun masih ada siswa yang enggan dan merasa berat untuk melaksanakan sholat tersebut. Tujuan dari diwajibkannya shalat dhuhur berjamaah di sekolah ini adalah untuk membiasakan siswa agar rajin beribadah. Ini adalah salah satu cara untuk menanamkan nilai religius siswa dan kesadaran akan kewajibannya sebagai umat muslim. Selain kewajiban shalat berjamaah, upaya pembudayaan nilai religius dengan cara memberikan kesempatan pada siswa untuk melakukan pengembangan diri yang dilakukan setiap hari jumat selepas senam pagi bersama. Para siswa secara bergiliran setiap kelas bergantian untuk mengisi dan melaksanakan tugas pengembangan diri yang disaksikan oleh seluruh siswa madrasah dan dewan guru. Hal ini dinilai sangat positif dalam rangka meningkatkan keahlian siswa untuk tampil dimuka umum. Karena dalam kegiatan pengembangan diri tersebut, siswa menampilkan pidato, pembacaan ayat suci $\mathrm{Al}$ qur'an, puisi, drama, ataupun rebana, serta lain-lain.Dalam rangka meningkatkan kebersihan dan kesehatan serta keindahan madrasah, setiap hari jumat minggu keempat, seluruh komponen madrasah, dimulai dari kepala sekolah, dewan guru, Tata Usaha, siswa, dan penjaga sekolah terlibat dalam kebersihan bersama, serta menanam tanaman hias dan merawat keindahan madrasah. Selain dari itu setiap pagi hari selasa dan kamis, seluruh siswa melaksanakan tadarus al Qur'an dengan membaca surat-surat pendek dan doa-doa harian. Kegiatan tersebut adalah bentuk peribadatan yang diyakini dapat mendekatkan diri pada Allah SWT, serta dapat meningkatkan keimananan dan ketaqwaan yang berimplikasi pada sikap dan perilaku positif, dapat mengontrol diri, dapat tenang, lisan terjaga, dan istiqamah dalam beribadah.

\section{Deskripsi Data Kuantitatif}

Penyajian data dalam bentuk kuantitatif pada penelitian ini menguraikan hasil penelitian mulai dari awal hingga akhir. Adapun tahapantahapan tersebut adalah sebagai berikut:

\section{Madrasah Aliyah Negeri Bengkulu Selatan}

Hasil uji normalitas diketahui bahwa nilai signifikansi sebesar $0,962>0.05$, sehingga dapat disimpulkan bahwa data yang diuji berdistribusi normal.

\section{Deskriptif Data}

Hasil deskriptif data responden variabel yakni: Aversion Therapy (X1), Modelling (X2), dan Sikap Keagamaan Siswa (Y) Madrasah Aliyah Negeri Bengkulu Selatan digambarkan bahwa:

1) Aversion Therapy (X1) terdapat jumlah 39 siswa yang mengisi angket. Diperoleh hasil untuk; ratarata $($ mean $)$ sebesar 50.00; titik tengah (median) $=$ 53.00; nilai yang sering muncul (mode) $=53$; simpangan baku (standar deviasi) $=10.086$, tingkat penyebaran data (variance) $=101.737$; rentangan $($ range $)=35$; skor minimum dari data $=$ 29 dan skor maksimum dari data $=64$. Sedangkan jumlah skor keseluruhan sebesar 1950.

2) Modeling (X2) terdapat jumlah 39 siswa yang mengisi angket. Diperoleh hasil untuk; rata-rata 
(mean) sebesar 50.00; titik tengah (median) = 51.00; nilai yang sering muncul (mode) $=54$; simpangan baku (standar deviasi) $=10.071$, tingkat penyebaran data (variance) $=101.421$; rentangan $($ range $)=39$; skor minimum dari data $=$ 28 dan skor maksimum dari data $=67$. Sedangkan jumlah skor keseluruhan sebesar 1950.

3) Sikap Keagamaan Siswa (Y) terdapat jumlah 39 siswa yang mengisi angket. Diperoleh hasil untuk; rata-rata (mean) sebesar 49.97; titik tengah $($ median $)=51.00$; nilai yang sering muncul $($ mode $)=58 ;$ simpangan baku $($ standar deviasi $)=$ 9.938, tingkat penyebaran data (variance) = 98.762; rentangan (range) $=33$; skor minimum dari data $=33$ dan skor maksimum dari data $=66$. Sedangkan jumlah skor keseluruhan sebesar 1949.

\section{Analisis Korelasi Ganda untuk X1, X2 dengan Y}

Berdasarkan signifikansi : dari output data dengan pengolahan menggunakan SPSS 16.0, diketahui antara Aversion Therapy (X1) dengan Modelling (X2), nilai signifikansi $0.00<0.05$ yang berarti terdapat korelasi yang signifikan. Selanjutnya antara Aversion Therapy (X1) dengan dengan Sikap Keagamaan (Y), nilai signifikansi $0.00<0.05$ yang berarti terdapat korelasi yang signifikan. Terakhir antara Modelling (X2), nilai signifikansi $0.00<0.05$ yang berarti terdapat korelasing signifikan.

\section{Analisis Regresi Ganda untuk X1 dan X2 terhadap Y}

Berdasarkan hasil output analisis regresi ganda untuk X1 dan X2 dengan $\mathrm{Y}$ pada program SPSS 16.0, terdapat beberapa nilai antara lain: nilai koefisien regresi, thitung, nilai signifikansi, nilai Fhitung, Nilai R Square atau R2, dan lain.lain.

\section{Uji t Parsial}

Berdasarkan output coefficients di atas, diketahui bahwa nilai koefisien regresi variabel aversion therapy (X1) adalah sebesar 0.058 bernilai positif $(+)$, sehingga dapat dikatakan bahwa aversion therapy (X1) berpengaruh positif terhadap sikap keagamaan (Y). Pengaruh positif diartikan bahwa semakin meningkat aversion therapy (X1), maka akan meningkat pula sikap keagamaan (Y). Demikian juga halnya dengan nilai koefisien regresi variabel modelling (X2) adalah sebesar 0.815 bernilai positif $(+)$, sehingga dapat dikatakan bahwa modelling (X2) berpengaruh positif terhadap sikap keagamaan (Y). Pengaruh positif diartikan bahwa semakin meningkat modelling (X2), maka akan meningkat pula sikap keagamaan (Y)

Selanjutnya adalah untuk mengetahui apakah pengaruh tersebut signifikan atau tidak, maka nilai koefisien regresi dari aversion therapy (X1) ini akan diuji signifikannya dengan uji t parsial dalam analisis regresi. Adapun hasilnya adalah sebagai berikut: Berdasarkan hasil analisis regresi diperoleh nilai t hitung sebesar $0.516<\mathrm{t}$ tabel 2.042 , dan nilai signifikansi (Sig). $0.609>0.05$.maka dapat disimpulkan bahwa aversion therapy (X1) tidak berpengaruh signifikan terhadap Sikap Keagamaan (Y).

Sedangkan pengambilan keputusan dalam uji $t$ kedua adalah sebagai berikut: Berdasarkan hasil analisis regresi diperoleh nilai $\mathrm{t}$ hitung sebesar $7.240>\mathrm{t}$ tabel 2.042, dan nilai signifikansi (Sig). $0.000<0.05$.maka dapat disimpulkan bahwa modelling (X2) berpengaruh signifikan terhadap Sikap Keagamaan (Y).

\section{Uji F Simultan}

Uji F Simultan digunakan untuk mengetahui ada atau tidaknya pengaruh signifikan dalam uji $\mathrm{F}$, dengan cara membandingkan antara $\mathrm{F}$ hitung dengan nilai $\mathrm{F}$ tabel, dan dapat pula dengan cara membandingkan nilai signifikasi atau nilai probabilitas dari hasil perhitungan SPSS apakah nilai signifikansi tersebut lebih besar atau lebih kecil dari nilai standar statistik yakni 0.05 .

Berdasarkan output uji $\mathrm{F}$ simultan Anova $\mathrm{X} 1, \mathrm{X} 2$, terhadap $\mathrm{Y}$ diperoleh nilai $\mathrm{F}$ hitung sebesar $54.715>\mathrm{F}$ tabel sebesar 3.26. maka dapat ditarik kesimpulan bahwa variabel Aversion Therapy (X1) dan Modelling (X2) secara simultan berpengaruh terhadap variabel Sikap Keagamaan (Y). Demikian juga dengan signifikansi sebesar $0.000<0.05$, maka dapat disimpulkan bahwa variabel Aversion Therapy (X1) dan Modelling (X2) secara simultan berpengaruh terhadap variabel Sikap Keagamaan (Y).

\section{Madrasah Aliyah Makrifatul Ilmi Bengkulu Selatan \\ Uji Persyaratan Analisis \\ Berdasarkan output hasil uji normalitas,} diketahui bahwa nilai signifikansi sebesar 0,555 > 0.05 , sehingga dapat disimpulkan bahwa data yang diuji berdistribusi normal.

\section{Deskriptif Data}

Hasil deskriptif data responden variabel yakni: Aversion Therapy (X1), Modelling (X2), dan Sikap Keagamaan Siswa (Y) Madrasah Aliyah Negeri Bengkulu Selatan digambarkan bahwa:

1) Aversion Therapy (X1) terdapat jumlah 34 siswa yang mengisi angket. Diperoleh hasil untuk; ratarata (mean) sebesar 86.94; titik tengah (median) = 88.00; nilai yang sering muncul (mode) $=84$; simpangan baku (standar deviasi) $=6.954$, tingkat penyebaran data (variance) $=48.360$; rentangan (range) $=27$; skor minimum dari data $=71$ dan skor maksimum dari data $=98$. Sedangkan jumlah skor keseluruhan sebesar 2956. 
2) Modelling (X2) terdapat jumlah 34 siswa yang mengisi angket. Diperoleh hasil untuk; rata-rata (mean) sebesar 84.62; titik tengah (median) = 85.00; nilai yang sering muncul (mode) $=85$; simpangan baku (standar deviasi) $=9.105$, tingkat penyebaran data (variance) $=82.910$; rentangan (range) $=34$; skor minimum dari data $=63$ dan skor maksimum dari data $=97$. Sedangkan jumlah skor keseluruhan sebesar 2877.

3) Sikap Keagamaan Siswa (Y) terdapat jumlah 34 siswa yang mengisi angket. Diperoleh hasil untuk; rata-rata (mean) sebesar 89.26; titik tengah (median) $=91.00$; nilai yang sering muncul $($ mode $)=96$; simpangan baku (standar deviasi) $=$ 7.191, tingkat penyebaran data (variance) $=$ 51.716; rentangan (range) $=24$; skor minimum dari data $=75$ dan skor maksimum dari data $=99$. Sedangkan jumlah skor keseluruhan sebesar 3035 .

\section{Penyajian Data \\ Hasil Analisis Korelasi Ganda untuk X1, X2 dengan $Y$}

Berdasarkan signifikansi : dari output data dengan pengolahan menggunakan SPSS 16.0, diketahui antara Aversion Therapy (X1) dengan Modelling (X2), nilai signifikansi $0.00<0.05$ yang berarti terdapat korelasi yang signifikan. Selanjutnya antara Aversion Therapy (X1) dengan dengan Sikap Keagamaan $(\mathrm{Y})$, nilai signifikansi $0.03<0.05$ yang berarti terdapat korelasi yang signifikan. Terakhir antara Modelling (X2) dengan Sikap Keagamaan (Y), nilai signifikansi $0.00<0.05$ yang berarti terdapat korelasi signifikan.

\section{Hasil Analisis Regresi Ganda untuk X1 dan X2 terhadap Y}

Berdasarkan hasil output analisis regresi ganda untuk $\mathrm{X} 1$ dan $\mathrm{X} 2$ dengan $\mathrm{Y}$ pada program SPSS 16.0, terdapat beberapa nilai antara lain: nilai koefisien regresi, thitung, nilai signifikansi, nilai Fhitung, Nilai R Square atau R2, dan lain.lain.

\section{Uji t Parsial}

Berdasarkan output coefficients, diketahui bahwa nilai koefisien regresi variabel Aversion Therapy (X1) adalah sebesar 0.050 bernilai positif $(+)$, sehingga dapat dikatakan bahwa Aversion Therapy (X1) berpengaruh positif terhadap Sikap Keagamaan (Y). Pengaruh positif diartikan bahwa semakin meningkat Aversion Therapy (X1), maka akan meningkat pula Sikap Keagamaan (Y). Demikian juga halnya dengan nilai koefisien regresi variabel modelling (X2) adalah sebesar 0.601 bernilai positif $(+)$, sehingga dapat dikatakan bahwa modelling (X2) berpengaruh positif terhadap Sikap Keagamaan (Y). Pengaruh positif diartikan bahwa semakin meningkat modelling (X2), maka akan meningkat pula Sikap Keagamaan (Y)
Selanjutnya adalah untuk mengetahui apakah pengaruh tersebut signifikan atau tidak, maka nilai koefisien regresi dari Aversion Therapy (X1) ini akan diuji signifikannya dengan uji t parsial dalam analisis regresi. Berdasarkan hasil analisis regresi diperoleh nilai t hitung sebesar $0.353<\mathrm{t}$ tabel 2.042, dan nilai signifikansi (Sig). $0.762>0.05$.maka dapat disimpulkan Aversion Therapy (X1) tidak berpengaruh signifikan terhadap Sikap Keagamaan (Y)".

Berdasarkan hasil analisis regresi uji t kedua diperoleh nilai $\mathrm{t}$ hitung sebesar 5.587 $>\mathrm{t}$ tabel 2.042, dan nilai signifikansi (Sig). $0.000<0.05$.maka dapat disimpulkan bahwa Modelling (X2) berpengaruh signifikan terhadap Sikap Keagamaan (Y)”.

\section{Uji F Simultan}

Uji F Simultan digunakan untuk mengetahui ada atau tidaknya pengaruh signifikan dalam uji $\mathrm{F}$, dengan cara membandingkan antara $\mathrm{F}$ hitung dengan nilai $\mathrm{F}$ tabel, dan dapat pula dengan cara membandingkan nilai signifikasi atau nilai probabilitas dari hasil perhitungan SPSS apakah nilai signifikansi tersebut lebih besar atau lebih kecil dari nilai standar statistik yakni 0.05 .

Berdasarkan hasil output uji F Simultan Anova X1,X2, Terhadap Y diperoleh nilai $\mathrm{F}$ hitung sebesar $25.689>\mathrm{F}$ tabel sebesar 3.33. maka dapat ditarik kesimpulan bahwa variabel Aversion Therapy (X1) dan Modelling (X2) secara simultan berpengaruh terhadap variabel Sikap Keagamaan (Y). Demikian juga dengan signifikansi sebesar $0.000<$ 0.05, maka dapat disimpulkan bahwa variabel Aversion Therapy (X1) dan Modelling (X2) secara simultan berpengaruh terhadap variabel Sikap Keagamaan (Y).

\section{Madrasah Aliyah Al Quraniyah Bengkulu Selatan Uji Persyaratan Analisis}

Adapun pengujian normalitas data diketahui bahwa nilai signifikansi sebesar 0,271 $>0.05$, sehingga dapat disimpulkan bahwa data yang diuji berdistribusi normal.

\section{Deskriptif Data}

Hasil deskriptif data responden variabel yakni: Aversion Therapy (X1), Modelling (X2), dan Sikap Keagamaan Siswa (Y) Madrasah Aliyah Negeri Bengkulu Selatan digambarkan bahwa:

1) Aversion Therapy (X1) terdapat jumlah 24 siswa yang mengisi angket. Diperoleh hasil untuk; ratarata (mean) sebesar 50.04; titik tengah (median) = 51.50; nilai yang sering muncul (mode) $=55$; simpangan baku (standar deviasi) $=10.174$, tingkat penyebaran data (variance) $=103.520$; rentangan $($ range $)=38$; skor minimum dari data $=$ 28 dan skor maksimum dari data $=66$. Sedangkan jumlah skor keseluruhan sebesar 1201. 
2) Modelling (X2) terdapat jumlah 24 siswa yang mengisi angket. Diperoleh hasil untuk; rata-rata (mean) sebesar 50.08; titik tengah (median) = 51.00; nilai yang sering muncul (mode) $=55$; simpangan baku (standar deviasi) $=9.899$, tingkat penyebaran data (variance) $=97.993$; rentangan (range) $=34$; skor minimum dari data $=30$ dan skor maksimum dari data $=64$. Sedangkan jumlah skor keseluruhan sebesar 1202.

3) Sikap Keagamaan Siswa (Y) terdapat jumlah 24 siswa yang mengisi angket. Diperoleh hasil untuk; rata-rata (mean) sebesar 50.00; titik tengah $($ median $)=52.50$; nilai yang sering muncul $($ mode $)=52$; simpangan baku (standar deviasi $)=$ 10.030 , tingkat penyebaran data (variance) $=$ 100.609; rentangan $($ range $)=33$; skor minimum dari data $=28$ dan skor maksimum dari data $=61$. Sedangkan jumlah skor keseluruhan sebesar 1200

\section{Penyajian Data \\ Hasil Analisis Korelasi Ganda untuk X1, X2 dengan $Y$}

Berdasarkan signifikansi : dari output data dengan pengolahan menggunakan SPSS 16.0, diketahui antara Aversion Therapy (X1) dengan Modelling (X2), nilai signifikansi $0.01<0.05$ yang berarti terdapat korelasi yang signifikan. Selanjutnya antara Aversion Therapy (X1) dengan dengan Sikap Keagamaan $(\mathrm{Y})$, nilai signifikansi $0.03<0.05$ yang berarti terdapat korelasi yang signifikan. Terakhir antara Modelling (X2) dengan Y, nilai signifikansi $0.09>0.05$ yang berarti tidak terdapat korelasi yang signifikan.

\section{Hasil Analisis Regresi Ganda untuk X1 dan X2 terhadap $Y$}

Berdasarkan hasil output analisis regresi ganda untuk $\mathrm{X} 1$ dan $\mathrm{X} 2$ dengan $\mathrm{Y}$ pada program SPSS 16.0, terdapat beberapa nilai antara lain: nilai koefisien regresi, thitung, nilai signifikansi, nilai Fhitung, Nilai R Square atau R2, dan lain.lain.

\section{Uji t Parsial}

Berdasarkan output Coefficients, diketahui bahwa nilai koefisien regresi variabel Aversion Therapy (X1) adalah sebesar 0.422 bernilai positif $(+)$, sehingga dapat dikatakan bahwa Aversion Therapy (X1) berpengaruh positif terhadap Sikap Keagamaan (Y). Pengaruh positif diartikan bahwa semakin meningkat Aversion Therapy (X1), maka akan meningkat pula Sikap Keagamaan (Y). Demikian juga halnya dengan nilai koefisien regresi variabel modelling (X2) adalah sebesar 0.253 bernilai positif $(+)$, sehingga dapat dikatakan bahwa modelling (X2) berpengaruh positif terhadap sikap keagamaan (Y). Pengaruh positif diartikan bahwa semakin meningkat modelling (X2), maka akan meningkat pula sikap keagamaan (Y)
Selanjutnya adalah untuk mengetahui apakah pengaruh tersebut signifikan atau tidak, maka nilai koefisien regresi dari Aversion Therapy (X1) ini akan diuji signifikannya dengan uji t parsial dalam analisis regresi. Dari hasil analisis regresi diperoleh nilai t hitung sebesar $1.938<\mathrm{t}$ tabel 2.080 , dan nilai signifikansi (Sig). $0.066>0.05$.maka dapat disimpulkan bahwa Aversion Therapy (X1) tidak berpengaruh signifikan terhadap Sikap Keagamaan (Y)".

Berdasarkan hasil analisis regresi diperoleh nilai $\mathrm{t}$ hitung sebesar $1.131<\mathrm{t}$ tabel 2.080 , dan nilai signifikansi (Sig). $0.271>0.05$.maka dapat disimpulkan bahwa Modelling (X2) berpengaruh signifikan terhadap Sikap Keagamaan (Y)".

\section{Uji F Simultan}

Uji F Simultan digunakan untuk mengetahui ada atau tidaknya pengaruh signifikan dalam uji $\mathrm{F}$, dengan cara membandingkan antara $\mathrm{F}$ hitung dengan nilai $\mathrm{F}$ tabel, dan dapat pula dengan cara membandingkan nilai signifikasi atau nilai probabilitas dari hasil perhitungan SPSS apakah nilai signifikansi tersebut lebih besar atau lebih kecil dari nilai standar statistik yakni 0.05 .

Berdasarkan hasil Output Uji F Simultan Anova X1,X2, Terhadap Y, diperoleh nilai $\mathrm{F}$ hitung sebesar $6.459>\mathrm{F}$ tabel sebesar 3.44. maka dapat ditarik kesimpulan bahwa variabel Aversion Therapy (X1) dan Modelling (X2) secara simultan berpengaruh terhadap variabel Sikap Keagamaan (Y). Demikian juga dengan signifikansi sebesar $0.007<$ 0.05, maka dapat disimpulkan bahwa variabel Aversion Therapy (X1) dan Modelling (X2) secara simultan berpengaruh terhadap variabel Sikap Keagamaan (Y).

\section{Kesimpulan}

\section{1) Simpulan Kualitatif}

a. Pada umumnya sikap keagamaan siswa MA Bengkulu Selatan sudah baik. Walaupun masih ada pelanggaran tata tertib yang dilakukan oleh siswa di madrasah. Pelanggaran tersebut dikarenakan siswa belum sepenuhnya memahami akan pentingnya pelajaran akidah akhlak. Selain dari itu faktor lingkungan sangat mempengaruhi sikap dan tindakan siswa Madrasah Aliyah Bengkulu Selatan.

b. Perencanaan pembelajaran yang dibuat oleh guru mata pelajaran akidah akhlak belum sepenuhnya baik, karena keterbatasan pengetahuan dan pemahaman guru dalam membuat perencanaan pembelajaran.

c. Pelaksanaan pembelajaran masih kurang menarik. Hal ini dikarenakan guru mata pelajaran akidah akhlak masih dominan menggunakan metode ceramah dan diskusi, dan belum sepenuhnya dapat mengembangan 


\section{Haril Penelition}

metode pembelajaran dengan baik ataupun berinovasi dan berkolaborasi dengan metode lainnya.

d. Dampak multidimensi pembelajaran akidah akhlak sangat berpengaruh pada sikap keagamaan siswa Bengkulu Selatan. Perubahan tersebut nampak setelah diterapkannya metode aversion therapy, dan metode modelling yang merupakan bagian kecerdasan ganda (multiple intelligences), yang secara rutin dilakukan di Madrasah Aliyah Bengkulu Selatan.

e. Implementasi metode aversion therapy dapat memberikan hukuman atas tindakan siswa yang telah menyimpang, atau pengobatan dari tindakan tersebut, serta dapat dijadikan sebagai pencegahan dari tindakan yang kurang baik

f. Untuk memperkuat implementasi metode aversion therapy, dilakukan penunjukan siswa sebagai modelling yang bertujuan untuk memberikan contoh akhlak yang baik, terutama untuk dirinya sendiri dan temantemannya

g. Sikap keagamaan siswa Madrasah Aliyah Bengkulu Selatan nampak sedikit berubah dengan impelentasi metode ini dalam pelaksanaan pembelajaran, hal ini terlihat jelas khususnya dalam proses pelaksanaan pembelajaran di kelas. Siswa yang sebelumnya malas untuk belajar, maka dengan metode ini siswa lebih antusias dan bersemangat dalam mengikuti rangkaian kegiatan pembelajaran.

\section{2) Simpulan Kuantitatif}

a. Metode aversion therapy tidak berpengaruh secara signifikan terhadap sikap keagamaan siswa.

b. Metode modelling berpengaruh secara signifikan terhadap sikap keagamaan siswa.

c. Berdasarkan signifikansi, metode aversion therapy dan modelling berpengaruh secara simultan terhadap sikap keagamaan siswa.

\section{Daftar Pustaka}

Abdullah Sani, Ridwan, (2014). Inovasi Pembelajaran, Jakarta: Bumi Aksara.

Adullah, Faisal, (2013). Motivasi Anak Dalam Belajar, Palembang: Noer Fikri.

Ahmadi, Abu, (2009). Psikologi Sosial, Jakarta: Rineka Cipta.

Arikunto, Suharsimi, (2010). Prosedur Penelitian, Jakarta: Rineka Cipta.

Bertens. K, (2016). Psikoanalisis Sigmund Freud, Jakarta: PT Gramedia Pustaka Utama.

Chatib, Munif, (2016). Gurunya Manusia, Bandung: Kaifa.
Chatib,Munif. (2012). Sekolahnya Manusia, (Bandung: Kaifa, cet. XV.

Danim, Sudarman, dan Khairil, Psikologi Pendidikan, Bandung: Alfabeta,2014

Depdikbud, (2005). Kamus Besar Bahasa Indonesia, Jakarta,Balai Pustaka.

Dimyati, (1999). Belajar Dan Pembelajaran, Rineka Cipta : Jakarta.

Fu'ad, Muhammad bin Abdul Baqi, (2014). Hadits Shahih Bukhari Muslim, Jawa Barat: PT. Fathan Prima Media.

Gardner, Howard, (2013). Multiple Intelligences, terj. Zaimur, Yelvi Andri., Daras Books.

Gunawan, Imam, (2015). Metode Penelitian Kualitatif Teori dan Praktek, Jakarta : Bumi Aksara.

Hamalik, Oemar, (2010). Kurikulum dan Pembelajaran, Jakarta: Bumi Aksara.

Hamalik, Oemar, (2003). Perencanaan Pengajaran Berdasarkan Pendekatan Sistem, Jakarta: Bumi Aksara.

Hamali, Syaiful, (2011). Sikap Keagamaan Dan Pola Tingkah Laku Masyarakat Madani'.

Himpunan Peraturan Perundang-undangan, (2009). Undang-Undang SISDIKNAS, Bandung : Fokusmedia.

Hernowo, (2004). Sekolah Para Juara, Pengantar Penerbit Bandung: Kaifa.

Idi, Abdullah, (2011). Pengembangan Kurikulum Teori dan Praktik, Jogjakarta: Ar-Ruzz.

Jalaluddin, (2015). Psikologi Agama, Jakarta: Raja Grafindo Persada.

Jasmine,Julia, (2007). Panduan Praktis Mengajar Berbasis Multiple Intelligences, Bandung: Nuansa.

Kencana Syafiie, Inu, (2011). Teori Keseimbangan, (Jakarta: Rineka Cipta.

Kamus Digital Bahasa Indonesia (KBBI), V1.1.

Khodijad, Nyayu, (2016). Psikologi Pendidikan, Jakarta: PP Rajagrafindo Persada.

Kosasih Nandang, (2013). Pembelajaran Quantum dan Optimalisasi Kecerdasan, Bandung: Alfabeta.

Kementrian Agama RI, (2015). Buku Siswa Akidah Akhlak Kelas XI.

Nata, Abuddin, (2010). Metodologi Studi Islam, Jakarta: PT Rajagrafindo Persada.

Rahman, Arief, (2014). Selayang Pandang MAN Manna, Palembang: Noer Fikri.

Riduwan, (2009). Metode dan Teknik Menyusun Tesis, Bandung: Afabeta.

Roestiyah, (2008). Strategi Belajar Mengajar, Jakarta: Renika Cipta.

Said, Alamsyah, (2015). 95 Strategi Mengajar Multiple Intelligences, Jakarta: Prenadamedia Group.

Sarmono W Sarlito, (2011). Psikologi Remaja, Jakarta: PT Raja Grafindo Persada. 
Sanjaya, Wina, Strategi Pembelajaran, Jakarta: Prenadamedia Group, 2016.

Siregar, Eveline dan Nara, Hartini, (2010). Teori Belajar dan Pembelajaran, Bogor: Ghalia Indonesia.

Setyosari Punaji, (2013). Metode Penelitian Pendidikan dan Pengembangan, Jakarta: Kencana.

Slameto, (2010). Belajar dan Faktor-Faktor Yang Mempengaruhinya, Jakarta: Rineka Cipta,

Sugiyono, (2009). Memahami Penelitian Kualitatif, Bandung: Afabeta.

Sugiyono, (2010). Statistika Untuk Penelitian, Bandung: Alfabeta.

Sugiyono, (2015). Metode Penelitian Pendidikan, Bandung: Alfabeta.

Sudjana,Nana, (1995). Dasar-dasar Proses Belajar Mengajar, (Bandung: Sinar Baru Algensindo.

Surya Sutan, (2006). Melejitkan Multiple Intelligences Anak Usia Dini, Yogyakarta: $\mathrm{CV}$. Andi Offset.

Wahab, Rohmalina, (2015). Psikologi Belajar, PT Raja Grafindo Persada.

Yuni, Y, Model (2015). Pembelajaran Dengan Pendekatan Psikoanalisis Melalui Metode Aversion Therapy dan Home Work, Alfabetha. 